\section{La Alhambra de Manguinhos: islamofilia y función ornamental en el Castelo Mourisco de Río de Janeiro}

\section{The Manguinhos Alhambra: islamophilia and ornamental function in the "Castelo Mourisco" in Rio de Janeiro}

\author{
José Manuel Rodríguez Domingo ${ }^{i}$ \\ i Profesor, Universidad de Granada. \\ Granada - Andalucía - España. \\ orcid.org/0000-0001-5714-0766 \\ jmrd@ugr.es
}

Recebido em 12 ago. 2019.

Aprovado em 14 jan. 2020.
RODRÍGUEZ DOMINGO, José Manuel. La Alhambra de Manguinhos: islamofilia y función ornamental en el Castelo Mourisco de Río de Janeiro. História, Ciências, Saúde-Manguinhos, Rio de Janeiro, v.27, n.2, abr.-jun. 2020, p.583606.

\section{Resumen}

El llamado Castelo Mourisco constituye un modelo exacto de la función elevada que corresponde a la arquitectura. Más interesante todavía cuando se trata de la sede de un instituto de ciencias biomédicas de prestigio mundial, cuyo cuidado diseño evidencia el compromiso humanista de Oswaldo Cruz, su impulsor. Solo gracias a la impecable alianza entre promotor $y$ proyectista pueden lograrse realizaciones arquitectónicas como ésta, donde se traspasan los límites constructivos hasta simbolizar la fusión de ciencia, historia y arte. El análisis de los variados recursos estilísticos utilizados en el edificio justifica su elección y vigencia, pues desde hace un siglo no solo ocupa el corazón del campus de Manguinhos, sino que también actualiza el espíritu de la institución que alberga.

Palabras clave: orientalismo; islamofilia; alhambrismo; ornamento; moorish revival.

Abstract

The so-called Castelo Mourisco provides an accurate model of the elevated function of architecture. It is all the more interesting because it is the headquarters of an internationally-renowned institute of biomedical sciences, and its meticulous design reveals the humanist ideals of Oswaldo Cruz, its founder. Only through a faultless alliance between founder and designer can architectural creations like this one arise; it transcends the limits of construction to symbolize the fusion of science, history and art. Analysis of the various stylistic resources used in the building justifies their selection and continued relevance, since for a century it has not only occupied the heart of the Manguinhos campus, but also continued to express the modern spirit of the institution it harbors.

Keywords: orientalism; islamophilia; alhambrism; ornament; Moorish revival. 
$\mathrm{E}^{\prime}$ l edificio que en la actualidad acoge la presidencia de la Fundación Oswaldo Cruz (Río de Janeiro) constituye un modelo fascinante en torno a las posibilidades del ornamento como configurador de la identidad del edificio. La relación armónica entre función y uso como esencia arquitectónica, que hallamos en el conocido Castelo Mourisco de Manguinhos, adquiere su dimensión precisa con el análisis de los elementos decorativos que lo completan. Sin embargo, a pesar del bien documentado proceso constructivo, resulta compleja la identificación del repertorio utilizado por el arquitecto constructor como fuente principal (Benchimol, 1990; Costa, 2003; Rodríguez Domingo, Melo, 2015). Una dificultad implícita en la práctica totalidad de los historicismos decimonónicos, de la que resulta imprescindible para la actualidad creativa marcar la distancia entre los modelos y sus obras derivadas.

La mayor parte de los estudios que han abordado el orientalismo arquitectónico, ya de forma generalista, ya centrando el análisis de un edificio, pasan de soslayo sobre las cuestiones formales. Parecen predominar los prejuicios formalistas que atribuyen a los arquitectos de la segunda mitad del siglo XIX y principios del siglo XX una absoluta falta de rigor en la manipulación de los códigos de la arquitectura histórica. Un escaso interés que, presumiblemente, habría sido compartido por clientes y público, incapaces de distinguir los formularios estilísticos. Sin embargo, en una época donde la enseñanza de la historia de la arquitectura era prioritaria en las escuelas profesionales y las discusiones estilísticas centraban los debates teóricos resulta injusto considerar que el recurso historicista estuviese exento de toda significación. Antes al contrario, la elección formal era tan consciente que con frecuencia se recurría a diferentes fuentes, allí donde el acceso a la información gráfica estaba asegurada.

En este tiempo, los futuros arquitectos en las academias de bellas artes y escuelas de arquitectura europeas y americanas debían cursar nuevas asignaturas como historia de la arquitectura, teoría del arte y de la decoración, copia de edificios antiguos y modernos, adornos y dibujos de arquitectura. Y las bibliotecas estaban bien nutridas con nuevos manuales y tratados de arquitecturas del pasado, donde las del Oriente islámico ocupaban un espacio tan destacado como los monumentos nacionales. El estudiante tenía acceso así a "tratados especiales de estilo latino, del bizantino, del ojival, del árabe y del Renacimiento, acompañados de los planos, alzados y detalles de sus principales monumentos". Todo ello reforzado con buenas colecciones "de vaciados de ornamentación plateresca y árabe ... así como otros detalles de estilo romano-bizantino". Un excepcional mundo gráfico suficiente "para connaturalizarlos [a los alumnos] con los diversos estilos" (Caveda, 1867, p.291).

Coincidente con esta actitud, las naciones europeas emprendieron un auténtico movimiento de defensa de las artes islámicas partiendo para ello del descubrimiento, estudio y promoción llevado a cabo por arquitectos-decoradores bajo la pretensión de reorientar la actualidad del ornamento. El llamado "Renacimiento oriental" hallaría entonces tanto elaboración teórica como legitimidad histórica mediante su inclusión en el relato historiográfico occidental y la creación de grandes corpus de imágenes - cromolitografías, fotografías, vaciados y coleccionismo de objetos de todo tipo - que sirvieron de modelos para los profesionales de la arquitectura y la decoración. Como se verá, de todos los recursos 
aplicados por Luiz de Moraes Júnior en el diseño del primitivo Instituto de Manguinhos, sin duda serían los procedentes del arte nazarí los más recurrentes. En este sentido, cabe recordar que la construcción poética de la Alhambra de Granada (España) ejerció una extraordinaria eficacia estética determinando la modernidad artística hasta las primeras vanguardias. Pero del mismo modo que los viajeros y escritores románticos desarrollaron el paradigma alhambreño, al que no pudo sustraerse cualquier orientalista dominado por una verdadera exigencia creadora, la disección entomológica llevada a cabo sobre el antiguo alcázar nazarí determinó la evolución moderna del diseño y las artes industriales.

\section{Orientalismo o "islamofilia"}

La asimilación por parte de la arquitectura occidental de las formas decorativas del arte islámico supuso una suerte de liberación más radical que la irrupción del propio orientalismo en las artes plásticas y la literatura. Ello dio lugar a desarrollos arquitectónicos desinhibidos, capaces de cumplir con su función de evocación, sin las limitaciones del academicismo. La "islamofilia" europea del siglo XIX, tal y como es definida por algunos autores (Labrusse, 2007), resulta del expansionismo colonial emprendido por ciertas potencias como Francia, Reino Unido o Alemania, aprovechando la decadencia del imperio otomano y la apertura de las vías comerciales hacia Extremo Oriente. Un fenómeno coincidente con el proceso de reflexión identitaria que halló en el extenso y variado muestrario decorativo del islam elementos suficientes para la renovación de las llamadas artes aplicadas y la reorientación de las prácticas decorativas. Pues el recurso "árabe" o "morisco" mostraba a Occidente caminos que iban más allá de los estrechos límites de lo decorativo, legitimando la idea de renacimiento como tal, independientemente de su ámbito de aplicación.

De este modo, en el Castelo de Manguinhos encontramos un ejemplo acabado de "islamofilia", donde lo islámico no debe ser entendido bajo un sentido religioso, sino esencialmente cultural, desde al-Ándalus a la India musulmana, pasando por las culturas árabes, turcas o iraníes. En cualquier caso, la práctica islamófila no se apoyaba sobre conocimientos culturales exactos, dado que se trataba antes que nada de una recreación condicionada por las necesidades contemporáneas de las sociedades occidentales. Un argumento a favor de que este objeto de pensamiento nuevo parte de una $\varphi$ ıı (filia), es decir, un vínculo amoroso, es que debe ser abordado desde la intuición afectiva dominante sobre la razón y el conocimiento. Esta reacción puede tener orígenes diversos, desde una estancia en el sur de España o El Cairo, la visita a una exposición universal o la lectura de una revista ilustrada. Por tanto, la idea de "islamofilia" supone una sensibilidad que coloca al islam como un sujeto con el cual dialogar, y no simplemente un objeto que comprender, representar o controlar, según proponía el orientalismo erudito, artístico y político, respectivamente.

En buena medida, a diferencia del pintor orientalista que no pretendía modificar su concepción de la imagen, el amante del arte islámico buscaba profundizar en este aspecto hasta transformar su mirada mediante la adopción de nuevas reglas de construcción y de visión formal. A pesar de ello, la voluntad de transformación del arquitecto orientalista 
no implicaba el deseo de perder su identidad. No se olvide que la lección del ornamento islámico en este tiempo no sería de orden semántico sino de carácter morfológico; lo cual no suponía el abandono de la lengua propia en favor de otra, sino la aspiración de remontar hasta los principios de creación de la forma con objeto de reorientar y renovar su propio lenguaje. Una vez desvelados los fundamentos lógicos de una morfología de la decoración, se podía aspirar a la superación de las determinaciones culturales a favor de un universalismo estético por parte de la decoración.

Es así que el trabajo de comprensión llevado a cabo en este tiempo por arquitectos y decoradores respondía a un doble proceso, resultado de dos visiones complementarias. De un lado, la evocación suscitada por el viaje, el libro de viaje o la imagen plástica que en el promotor estaba asociada a una visión pintoresca y romántica que se nutría de una relación pasional y melancólica con el pasado medieval. Mientras que el arquitecto y el decorador, para dar forma al sueño del cliente, habían de recurrir a las publicaciones de vocación científica, integradas por modelos de composiciones ornamentales, mediante cuidadas láminas en su mayoría descontextualizadas.

De hecho, el elemento que caracteriza la arquitectura islámica para el arquitecto occidental no será el volumen, ni el espacio, sino la decoración. De ahí el extraordinario valor que asumen las formas en el Castelo, desde los arcos que enmarcan los vanos a los paneles de mortero y yeso que recubren paredes y techos. El ornamento no figurativo posee la función de imprimir una armonía específica a la percepción espacial. Precisamente, uno de los principales argumentos de estos profesionales en la defensa de la gramática oriental era su universalidad, por lo que resultaba especialmente aplicable a la sociedad industrial occidental. Como consecuencia, se dispuso de precisos repertorios capaces de consolidar el mauresque - moorish, maurischer, moresco o mourisco - como alternativa autónoma, elevada más tarde a categoría estilística. El arquitecto ecléctico aprendió entonces a seleccionar y combinar elementos de procedencia diversa con objeto de generar un todo homogéneo y armonioso, aspiración solo alcanzable con verdadero talento artístico.

De igual modo que los "árabes" habían asumido el roleo grecorromano no para imitarlo, sino para generar el arabesco, el artista contemporáneo era consciente que las imbricaciones geométricas de los arabescos no implicaba reproducirlos de forma exacta ni recuperar a través de ellos un tipo de cultura medieval o morisca. Sino que, antes al contrario, eran el camino para desentrañar las leyes generales de la armonía y el dinamismo que estaban implícitas en las cortinas nazaríes, en los tapices safávidas o en las cerámicas timúridas, pudiendo transformarse según las necesidades de la sociedad industrial contemporánea. Es decir, más allá de la importación estilística directa, esta reflexión sobre el ornamento permitió generar una "gramática de adornos" adaptable a las condiciones culturales de los modernos arquitectos, decoradores y artistas.

Por tanto, solo la competencia histórico-técnica de los arquitectos podría dar lugar a experiencias absolutamente fascinantes como el Castelo Mourisco de Río de Janeiro. Un proceso para el que tan determinante sería la personalidad del promotor, quien al fin y al cabo estableció las condiciones y objetivos del proyecto. 


\section{Un arquitecto para un cliente}

La legitimidad del hecho arquitectónico está basada en la relación simétrica entre profesional y cliente, asentada sobre el doble registro de la experiencia y la confianza mutuas. La pareja conformada por el arquitecto y su cliente suele estar así fundada sobre relaciones equívocas, lo cual ha permitido a Rem Koolhaas (1996, p.12) afirmar, no sin cierto cinismo, que "la arquitectura es una actividad peligrosa pues se trata de una mezcla envenenada de impotencia y de omnipotencia, en el sentido de que el arquitecto organiza las fantasías megalomaníacas de otros, así como las circunstancias, para imponer estos fantasmas y estos sueños". De ahí que la profesión de arquitecto se considere, por la fuerza de las circunstancias, un oficio que gira en torno al modo de seducir; especialmente cuando el urbanismo, entendido en el sentido albertiano de la ciudad como una gran casa, ha perdido su autoridad frente a la arquitectura, cuya principal belleza radica en su capacidad de encantar.

A la hora de analizar el carácter del edificio debe tenerse en cuenta que éste es el resultado de la confluencia de tres actores: la demanda social representada por el cliente, el legislador que planifica y organiza la relación del objeto con su entorno y el proyectista que adapta las exigencias del promotor a reglamentos y ordenanzas, asumiendo el aspecto funcional y artístico de la construcción. Este último elemento adquiere la mayor importancia por cuanto proyecta la obra hacia el exterior, hacia el espectador, con una gramática y sintaxis determinadas sobre las que confluyen elementos estructurales, materiales, técnicas y formas. Por todo ello, queda claro que la historia de la arquitectura no es el relato de los edificios, sino de los procesos que los generan.

Este planteamiento adquiere pleno sentido en el Castelo Mourisco, resultado de la estrecha relación mantenida a lo largo de casi dos décadas entre el científico Oswaldo Gonçalves Cruz (1872-1917) y el ingeniero Luiz de Moraes Júnior (1868-1955). Un vínculo que se inicia durante los trabajos de éste en la iglesia da Penha (Río de Janeiro), y alcanza su cenit tanto en la planificación del campus de Manguinhos como en la construcción de sus primeros pabellones (Costa, 1999, p.38). En todos los casos, Moraes aplicó esquemas de gran racionalidad, por tratarse de estructuras en las que debía dominar la funcionalidad sobre la representación. Como características generales de su proyectiva, cabe resaltar su adecuación a las tendencias formales y estéticas de la época, la extraordinaria habilidad para combinar elementos arquitectónicos y decorativos de estilos del pasado, la autonomía entre planificación y diseño formal, y sobre todo el empleo de materiales nobles y técnicas cuidadas que dotan a sus edificios de un refinamiento singular (Oliveira, 2007, p.343).

Tanto para el proceso de diseño, construcción y acabado del Instituto de Manguinhos, como para la planificación del resto del campus, a pesar de la innegable impronta de promotor y arquitecto, se aprecia la presencia del modelo de entrenamiento y trabajo plural aplicado a la formación de los investigadores del centro, donde resultaban esenciales el aprendizaje y la actualización del conocimiento para el desarrollo de la investigación científica. Esta preocupación por la información no solo constituía una estrategia básica como garantía de la especialización, sino también una forma de conjurar el secular retraso con que Brasil incorporaba los avances del progreso humano. En el trabajo en equipo, 
ya fuese de investigadores, como de operarios y artesanos, se hallaban las claves de la excelencia. Cabe suponer que la supervisión ejercida por Oswaldo Cruz sobre los trabajos de planificación y urbanización del campus sería tan estrecha como la aplicada en los encuentros de estudios cooperativos con sus investigadores que celebraba semanalmente en la sala de lectura de la institución. Es decir, de igual manera que estimulaba el intercambio de información científica por medio de la última bibliografía adquirida, debió valorar las novedades gráficas y constructivas aportadas por sus colaboradores en el diseño y construcción del instituto.

El pensamiento de Luiz de Moraes Júnior articula dos categorías de elementos como son, en primer lugar, el consciente, algo innato a su condición de portugués, de ibérico, de europeo en suma, y que influye necesariamente en su metodología para afrontar el problema arquitectónico. Aquí va implícita la dirección y racionalización del proceso de diseño, junto con la capacidad de análisis y resolución de problemas. Todo lo cual se complementa con la memoria de las formas y las figuras acumuladas, donde se combina la raigambre andalusí de sus recuerdos juveniles en el sur de Portugal con la formación en repertorios eclécticos franceses. Esta capacitación profesional y dominio de los códigos estilísticos le aportaría la seguridad necesaria para instalarse en Brasil hacia 1900.

La arquitectura burguesa e institucional brasileña había estado marcada hasta ese momento por la interpretación que de los estilos del pasado llevaron a cabo los arquitectos europeos emigrados al país americano, la mayoría de ellos formada en la tradición beauxarts y condicionada por la aplicación de los conceptos plásticos de simetría, composición y proporción. Igualmente, las intervenciones en Río de Janeiro durante todo el siglo XIX estuvieron limitadas al ámbito de la arquitectura individual, dentro de la cual el ornamento fue adquiriendo un desarrollo autónomo hasta democratizar las prácticas decorativas y extender su aplicación. Como muestra de este proceso cabe analizar las referencias a las artes del islam presentes en la arquitectura carioca, restringidas como potenciales recursos de distinción social, pero asociadas a una élite urbana cosmopolita, cuya ideología progresista se basaba en el positivismo y abominaba de su pasado colonial, sinónimo de sociedad agraria y esclavista (Needell, 1987). A pesar de esta negación de lo local y autóctono, la estampa del Castelo Mourisco recuerda en su frente enmarcado por torres el desaparecido Palácio Vrijburg en Recife, la primera obra civil de gran envergadura arquitectónica construida en Brasil, divulgada a través de estampas. En efecto, el también conocido como Palácio das Torres, fue erigido hacia 1640 en la isla de Antônio Vaz, ampliamente fortificado y rodeado de un extenso parque zoo-botánico que reunía abundantes especies tropicales. Este importante acervo proporcionó abundante material a los primeros tratados de historia natural de Brasil, como la Historia naturalis brasiliae (1648) de Willem Piso, que ha servido de base a sucesivas generaciones de científicos e investigadores. Por su parte, el médico y humanista holandés Caspar van Baarle había publicado un año antes Rerum octennium in Brasilia et alibi gestarum, ilustrada con dos grabados de Frans Post que reproducían una panorámica del palacio y su planta. La obra de este polímata fue reeditada en épocas sucesivas, alcanzando gran repercusión internacional; por lo que cabe suponer que fuese conocida de Oswaldo Cruz, de manera que el perfil torreado del palacio de Recife, rodeado de frondosa vegetación, entrara a formar parte del imaginario concebido para Manguinhos. 


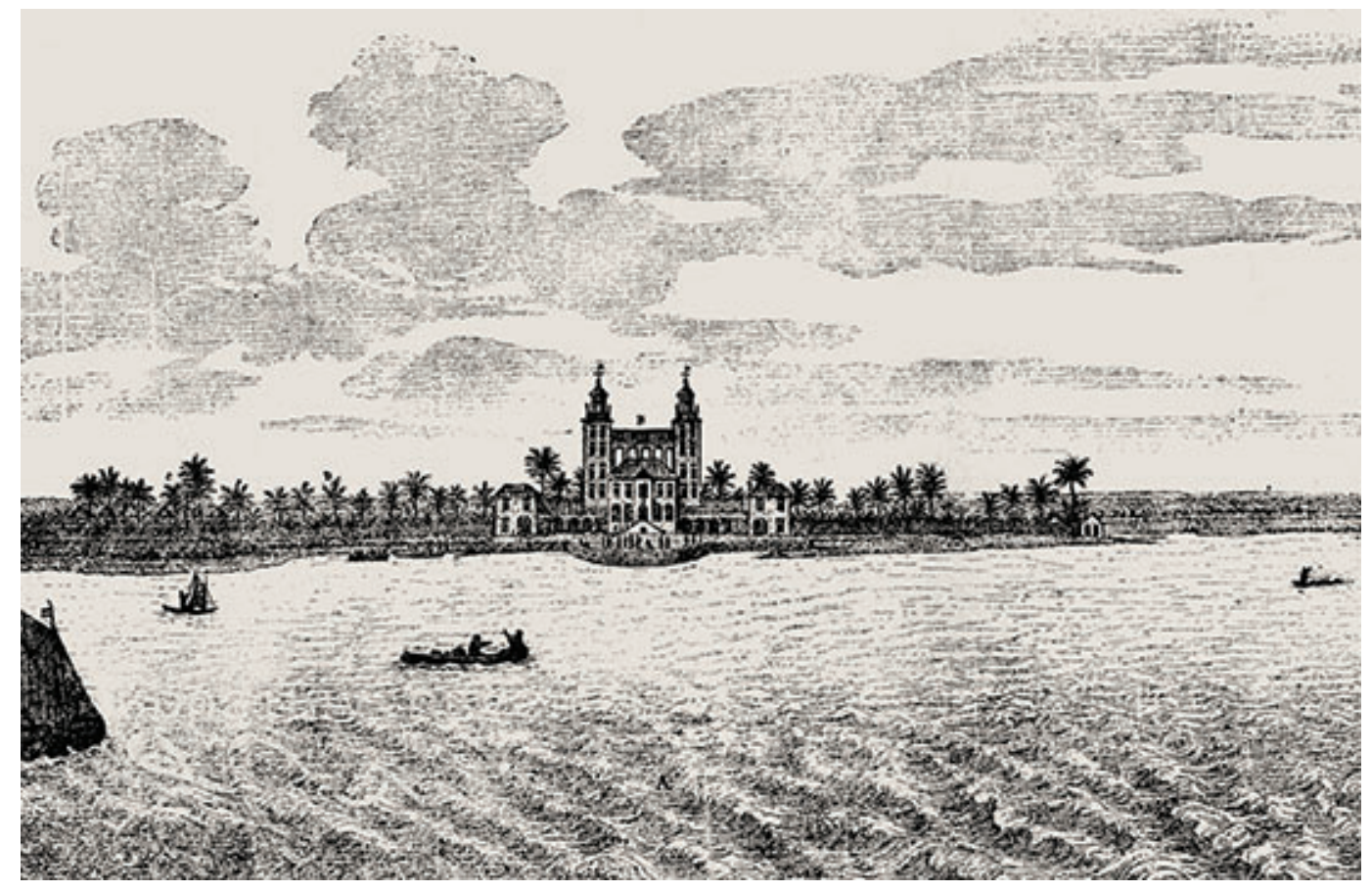

Figura 1: Vista del Palácio Vrijburg en Recife, por Frans Post (Van Baarle, 1648)

De entre todos los acontecimientos que marcaron el paso del Imperio a la República, ninguno alcanzó tanta trascendencia para la capital federal como la presidencia del paulista Francisco de Paula Rodrigues Alves; cuando se diera una insólita conjunción entre política, urbanismo y medicina con la presencia de Lauro Müller como ministro de Obras Públicas, del ingeniero Francisco Pereira Passos como prefecto del Distrito Federal y del médico Oswaldo Cruz al frente de la Dirección General de Salud Pública. De este modo, entre 1903 y 1908 Río de Janeiro alcanzó el punto culminante de su desarrollo como urbe moderna, superando la morfología colonial que había marcado su carácter hasta entonces, para convertirse en una de las grandes metrópolis continentales, gracias a la llamada "Reforma Passos" (Reis, 1977, p.27). En ello tuvo que ver la progresiva implantación del higienismo que, desde la proclamación de la República (1889) venía difundiendo sus tesis en los centros industriales, ciudades portuarias y capitales de estados, al amparo del triunfo de los postulados positivistas de orden y progreso.

Conviniendo en cómo el ser humano busca su identidad y expresión emocional en el espacio construido, no debe sorprender que se prestara un interés extraordinario al diseño de las nuevas construcciones, especialmente a sus fachadas, dado que si los monumentos del Imperio debían sugerir, inspirar y conmover, a los edificios del periodo republicano correspondía ahora el papel de representar (Brenna, 1987, p.56-57; RochaPeixoto, 2000, p.6). Sin embargo, la ausencia de criterios conceptuales caracterizó el eclecticismo dominante en la arquitectura brasileña entre 1860 y 1930, de manera que la importación de modelos y formas europeos prescindió de cualquier base ideológica que pudiera justificar su aplicación, fuera de la superficialidad de las modas y la apropiación 
de una imagen que reflejara el definitivo desarrollo socio-cultural y económico de la nación. De hecho, la ausencia de referencias más o menos directas a su propio pasado y tradición constructiva determinó la introducción de elementos cuya aplicación en la arquitectura europea resultaban históricamente inadmisibles. Véase algunos de los inmuebles construidos en la flamante avenida Central, como el Edificio Pérsico, diseñado por Adolfo Morales de los Ríos, o el Pabellón Morisco de Botafogo. No obstante, este eclecticismo de matriz francesa venía a interpretar y acentuar la diversidad racial y de nacionalidad del pueblo brasileño, posibilitando un viaje romántico soñador y fantástico (Rodríguez Domingo, 2012, 2016).

El proyecto para el edificio principal del Instituto Sueroterapéutico sufrió modificaciones significativas desde los primeros esbozos, conservados en el Departamento de Patrimonio Histórico de la Casa de Oswaldo Cruz. La ligereza de trazo y sus rasgos apresurados se atribuyen a la mano del propio Cruz, reflejando el pensamiento de un edificio llamativo y sugerente, quizás asociado a otros proyectos europeos que había conocido personalmente, como el conjunto neogótico de la Universidad Católica de Lille o del propio Instituto Pasteur, construido en esta ciudad francesa. A partir de aquí, Luiz de Moraes Júnior elaboró en 1905 un ostentoso plan que respetaba la articulación de vanos en dos plantas con tres cuerpos salientes propuesta por Cruz. La construcción de ladrillo se alzaba sobre un basamento de piedra, ventanas geminadas con arcos de herradura en los laterales, galería porticada superpuesta dominando la fachada, mirador sobre el pabellón de entrada, y merlones escalonados recorriendo la cornisa. A pesar del aspecto longitudinal del edificio, éste se ampliaba hacia atrás mediante la prolongación de las crujías laterales, hasta conformar una planta en $\mathrm{H}$. Una transformación, respecto del plan inicial, que permitía abrir las diferentes estancias a las galerías de las fachadas principal y trasera, introduciendo un eje vertebrador para sanitarios con la apariencia de una torre de castillo isabelino.

En cualquier caso, la explicación a la elección de uno u otro repertorio estilístico por parte del arquitecto se halla siempre en la voluntad del cliente, en su conocimiento directo o indirecto de determinados modelos. Se ha especulado acerca de la estancia de Oswaldo Cruz en Andalucía durante alguno de sus viajes europeos, lo cual no supone nada determinante habida cuenta de la proyección internacional que en torno a 1900 tenían monumentos como la Alhambra de Granada, la Giralda de Sevilla o la Mezquita de Córdoba. Además de estas referencias estéticas que, como persona ilustrada, Cruz debía conocer y admirar, también desempeñan un papel primordial en la definición de las prioridades artísticas y arquitectónicas de todo promotor su posición económica y social, así como la ideología y aspiraciones profesionales. En efecto, el prestigio alcanzado como científico y también como gestor político, avalaban el éxito de una empresa de las características de este Instituto, que contó con amplio respaldo financiero en su primera etapa de construcción. Por otra parte, aunque las verdaderas razones que determinaron la asimilación del formulario arquitectónico y decorativo islámico en el Castelo no están explicitadas, resulta plausible considerar el conjunto como monumento a las ciencias árabes, en concreto al periodo áureo medieval, cuando a las interpretaciones del saber 
de los griegos se agregó el de persas e indostánicos, junto con sus propias observaciones y experiencias (Costa, 2003, p.106). En cualquier caso, no se ocultaba a la crítica de la época el papel decisivo jugado por el científico paulista en toda esta obra: "Su construcción fue dirigida por el propio Oswaldo Cruz, quien hizo todo lo posible por mantener, en conjunto y en los detalles, las líneas y decoraciones del modelo arquitectónico elegido, en homenaje a los inventores del álgebra y a los sabios pontífices de la medicina medieval" (Fernandes, 1920, p.5).

Cruz no renegaba de lo autóctono, determinado por el emplazamiento y su entorno, si bien aspiraba a universalizar sus investigaciones a través de un edificio cosmopolita, sofisticado y políglota. ${ }^{1}$ En efecto, los diversos códigos estilísticos aplicados y la acabada asociación entre forma y función reflejan la internacionalización de un centro de investigación integrado por científicos americanos y europeos, al tanto de los últimos avances por el nivel de las revistas suscritas y que editaba un periódico científico - Memórias do Instituto Oswaldo Cruz - con artículos en portugués y su correspondiente versión en francés, inglés y alemán. La honda confianza en la política higienista desarrollada desde la Dirección General de Salud, así como la necesidad de respaldar cualquier iniciativa social en la investigación habían motivado la creación de un centro de vanguardia en el desarrollo científico y sanitario del país, envuelto bajo la apariencia de "un soberbio edificio, cuya fastuosidad y medios de enseñanza asombran" (La enseñanza..., 1923, p.225).

\section{Los modelos orientalistas}

La construcción del Instituto Sueroterapéutico Federal dio comienzo en 1905 con los trabajos de cimentación, siendo entonces cuando se produjo la primera modificación del diseño con la incorporación de dos torres con cúpulas como remate de los cuerpos laterales. La razón de esta reforma debemos buscarla en la excesiva regularidad de la fachada, apenas alterada por la sucesión de arcos de inspiración oriental, que no superaba la apariencia de una suntuosa villa burguesa. Resultaba por tanto imprescindible incorporar elementos que proyectasen una imagen sofisticada y atractiva, cuyo perfil hiciera al edificio perfectamente reconocible desde la distancia. La referencia directa de las torres, así como una mayor proximidad compositiva en la fachada principal, se halla en la Neue Synagogue (1859-1866) de Berlín. Este templo, construido en la Oranienburger Straße por la elite judía reformista, se convirtió en la mayor sinagoga del mundo una vez concluida, expresión de grandeza y buen gusto. De hecho, la crónica de la inauguración, el 5 de septiembre de 1866, proclamaba:

La nueva iglesia es un orgullo de la comunidad judía de Berlín, pero aún más, es un adorno de la ciudad, una de las creaciones más notables de la arquitectura moderna al estilo morisco y una de las empresas de construcción más distinguidas, que ha llevado a cabo la comunidad del norte de Alemania en los últimos años ... Pretende describir una estructura de cuento de hadas que, en medio de una zona bastante sobria de nuestro barrio, presenta las maravillas fantásticas de una Alhambra moderna con elegantes y ligeras columnas, amplias arquerías, coloridos arabescos, múltiples adornos, toda la magia del estilo árabe (Zeitungsnachrichten..., 18 sept. 1866, p.604). 


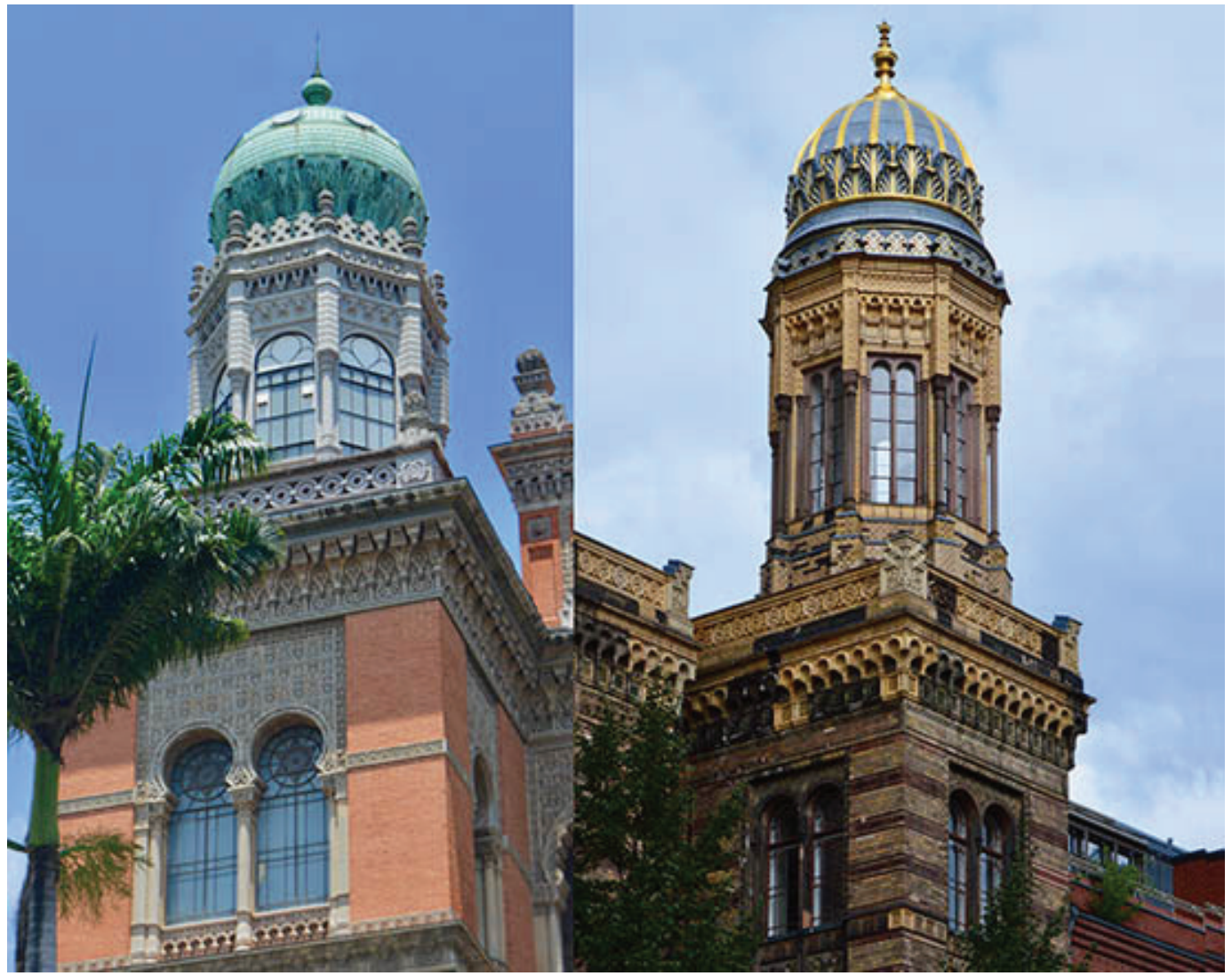

Figura 2: A la izquierda, torre del Castelo Mourisco, Río de Janeiro, y a la derecha, la de la Nueva Sinagoga, Berlín (Acervo personal del autor)

Este edificio demostraba la maleabilidad de la cultura orientalista y la evocación del esplendor de los judíos de al-Ándalus. La representación de sus interiores fueron publicados en el Illustrated London News, mientras que los dibujos y artículos de Gustav Knoblauch aparecieron en el Zeitschrift fuer Bauwesen, una revista de arquitectura fundada por su padre, Edouard Knoblauch, autor del diseño (Knoblauch, 1865, 1866, 1868). Las referencias a la Alhambra fueron destacadas en estos trabajos, siendo vinculadas a la comunidad sefardita y a la arquitectura de las sinagogas medievales hispanas; asimilación que no suscitó el entusiasmo del judaísmo ortodoxo. En cualquier caso, el éxito de esta obra sería extraordinario hasta convertirse en modelo para las sinagogas reformadas, extendiendo el monumentalismo de las fachadas jalonadas de esbeltas torres a modo de minaretes y suntuosas decoraciones alhambristas en el interior. Este esquema, aplicado en ámbitos urbanos, pretendía manifestar la presencia de la comunidad judaica en competencia con los templos cristianos (Efron, 2016, p.150-159). Las estampas fotográficas que reproducían el exterior de la sinagoga pronto dieron lugar a tarjetas postales que viajaron por todo el mundo difundiendo este símbolo de la prosperidad y embourgeoisement del Berlín judío (Bush, 2004, p.197).

La vistosidad, por tanto, de la fachada principal se adecuaba al interés de Oswaldo Cruz por hacer del Instituto un punto de referencia y atención ya desde su mismo diseño arquitectónico. 
Aprovechando así la participación del Instituto de Manguinhos en el décimo quinto Congreso Internacional de Higiene y Demografía (Berlín, 1907), se presentó el plan de campus en la Exposición de Higiene. Estas aportaciones, que incluían una maqueta del Castelo, obtuvieron la medalla de oro del certamen. Sin embargo, aunque la nueva incorporación equilibraba la excesiva horizontalidad del plan inicial, no se lograba la armonía compositiva que Knoblauch había alcanzado en la sinagoga germana. Por otra parte, la necesidad de aumentar la superficie útil del edificio, con despachos y laboratorios, llevó a incorporar una nueva planta, elevando la altura total del conjunto y obteniendo una definitiva armonía compositiva. También se incorporaron en este momento mayor número de elementos decorativos como las cornisas de mocárabes, las cresterías de remate y los flameros.

No obstante, en el pabellón de exposición es posible encontrar otras referencias plausibles, sustitutivas del orientalismo erudito y arqueológico por un nuevo espacio imaginario. Sería el caso del observatorio del parque de Montsouris (París), un servicio de análisis químicos y bacteriológicos que en realidad había sido diseñado como Palacio del Bey tunecino para la Exposición Universal de París de 1867, también conocido como Palacio del Bardo. El proyecto de Alfred Chapon utilizaba el modelo tradicional de villa suburbana envuelto en arcos de herradura, bandas bicromas, ajimeces, merlones y cúpulas, suficiente para dotarle de una apariencia exótica. La regularidad del diseño, cuya planta principal con pórtico abierto se alzaba sobre un basamento con escalinata, se repetiría en otras construcciones similares como el Chateau Mauresque de Comines, construido por el industrial Victor Hassebroucq (Sence, 2017), o el Café Orient de Wiesbaden.

En esta sucesión de influencias diversas que buscan integrarse en un proyecto único, es preciso fijar la atención en el desaparecido Chateau Vaissier (1892-1894), en la frontera francesa con Bélgica, que comparte con el Castelo Mourisco semejanzas más allá de los puramente formales. El exuberante conjunto residencial mandado edificar por el industrial Victor Vaissier suponía la culminación de una carrera meteórica en la acumulación de fama y fortuna. Con motivo de sus esponsales encargó al arquitecto Édouard Dupire-Rozan un palacio sin parangón en toda Francia, imagen de su marca comercial y de sí mismo, con el cual eclipsar cualquiera de las veleidades arquitectónicas de los empresarios textiles de la región. No cabe duda que la participación de las industrias Vaissier en las exposiciones universales debió estimular una imaginación proclive al exceso y al reclamo publicitario; resultando un desmesurado pabellón de muestra, irresistiblemente atractivo y contenedor de todas las experiencias imaginables, inmediato a la fábrica matriz de Tourcoing.

El Palacio del Congo, como sería conocido, remarcaba su origen en la fortuna acumulada por Vaissier mediante la fabricación de los afamados "Savons des Princes de Congo", los primeros jabones perfumados (Maury, 2013). El protectorado francés sobre este territorio centroafricano resultaba propicio para una marca comercial que durante dos décadas insertó más de seis mil poemas publicitarios en la prensa parisina, y se convirtió en proveedor oficial de Leopoldo II de Bélgica. El único inconveniente estribaba en la búsqueda de una identidad visual, para la cual la modesta arquitectura aborigen resultaba escasamente llamativa. De ahí que Vaissier optara por asociar la opulencia del imperio mogol a su marca de jabones, elección tan extravagante como deliberada, que justificaría la adopción de este estilo en la residencia del "maharajá de Roubaix", la más grande del norte de Francia. 
En esa relación necesaria, el promotor encontró en Dupire-Rozan al artífice más cualificado para llevar a buen término este proyecto, tanto por su excelencia técnica como por contar con una amplia experiencia en la construcción de viviendas de gran lujo, para las que su formación en l'École des Beaux-Arts de París acreditaba el dominio de la paleta estilística. Se trataba así de un enorme cubo de 33 metros de lado alzado sobre tres plantas, y coronado por una voluminosa cúpula bulbosa de cerámica vidriada y metal sobre tambor. Sin duda, éste era el elemento más rutilante del conjunto, con placas en tonos azafrán, rojo y azul turquesa, resaltadas de noche con electricidad. El arquitecto aplicó diferentes referencias relacionadas con la arquitectura mogol de la India, aunque combinadas con recursos de procedencia norteafricana, siguiendo los patrones mixtos de los pabellones de las exposiciones universales. Cada fachada aparecía horadada de balcones y ventanas, discurriendo una galería a manera de belvedere por tres de sus lados, y chhatris como remate del frente de entrada. El fabuloso parque diseñado por Jules Willem rodeaba la mansión, con cinco hectáreas de jardines entre los términos de Mouvaux, Tourcoing y Wasquehal.

La aceptación crítica de este conjunto llegó en 1897, cuando el palacio acogió una recepción del Congreso Nacional de Arquitectos celebrado en Lille. No satisfecho con la ubicación y dimensiones de su palacio, que permitían divisar su voluminosa cúpula a gran distancia, Vaissier difundió esta exótica estampa en multitud de tarjetas postales, como si se tratase de un afiche publicitario más de sus productos. Sería a través de este medio que las llamativas formas del edificio sirvieron de inspiración a otros arquitectos y promotores, caso de Luiz de Moraes Júnior. En concreto, las esbeltas torres de la fachada trasera de Tourcoing recuerdan la disposición volumétrica de las que enmarcan el frente del Castelo; de igual modo que las boínder o bow windows traseras, con triples arcos mixtilíneos de influencia mogol por influencia del indo-saracenic revival.

Asociaciones como ésta permiten demostrar la variedad de recursos formales utilizados por Moraes en el diseño del Castelo, donde el conocimiento de edificios contemporáneos proporcionaba diferentes modelos y suponían el aval necesario para una obra arriesgada. De hecho, un aspecto que debió determinar la denominación popular del edificio se halla en la costumbre de designar como château mauresque todo el extenso conjunto de palacetes suburbanos de influencia orientalista, construido en este tiempo. Pues el recurso a las ventanas geminadas con arcos de herradura, la alternancia de dovelas de piedra y ladrillo, o la utilización de cresterías y merlones, manifiestan un influjo dominante del style mauresque.

La fascinación de la Alhambra - de la que luego se abordará su influjo directo - no provenía del equilibrio de la masa arquitectónica, ni de la proporcionada distribución volumétrica, ni aun de su integración en un entorno paisajístico extraordinario, sino de la intrincada belleza de las decoraciones interiores. Así lo entendieron los arquitectos y decoradores que hallaron en el alhambrismo el esquema visual apropiado para ciertas tipologías de recreo, pronto asociadas al hedonismo oriental como cafés, fumoirs, baños públicos, teatros, circos, quioscos etc. Esta tendencia, extraordinariamente extendida desde mediados del siglo XIX, puede ser considerada como parangón de un orientalismo romántico progresivamente transformado en exotismo de bazar.

En todos los ejemplos señalados subyace la visión defendida por teóricos del ornamento como Charles Blanc o Jules Bourgoin, quienes llegaron a denunciar la superficialidad del 
arte morisco frente a la pureza del arte árabe. Sin entrar en las razones políticas que podrían justificar estas opiniones - conquista de Argelia (1830), protectorado de Túnez (1881) y Marruecos (1912) -, el modelo orientalista galo quedó definido por la competición estética con Gran Bretaña, quien siempre respaldó la superioridad del arte morisco propuesta por el arquitecto Owen Jones.

\section{La Alhambra como modelo}

Por su doble cualidad de monumento islámico y emblema europeo, la Alhambra representa por excelencia la estética del Islam, capaz de propiciar esa interiorización de los principios decorativos islámicos. Su excepcional prestigio visual cristalizó muy pronto la fascinación de los viajeros y la convirtió en uno de los hitos inaugurales del gran movimiento de redescubrimiento de las artes del islam por parte de los occidentales en el siglo XIX; ambos por la precocidad de su estudio detallado, desde finales del siglo XVIII, y por su rápida integración en la cultura de masas. En este sentido, las láminas con detalles decorativos de la Alhambra, contenidas en los libros de los teóricos Girault de Prangey y Owen Jones fueron utilizados por Moraes en el Castelo Mourisco. Incluso, el hallazgo de un ejemplar de la exitosa guía de Granada, de Albert F. Calvert, en la biblioteca personal de Cruz, ha llevado a considerar el influjo de la imagen de los palacios nazaríes. En cualquier caso, el mencionado libro, editado en 1904 y con sucesivas ediciones, ofrece el interés de recopilar una extensa documentación gráfica, desde las planchas cromolitográficas de Jones a fotografías de Rafael Garzón, Eloy Señán, Ernst Wasmuth y Eugen Twietmeyer, pasando por dibujos de John F. Lewis, grabados de James C. Murphy y la serie Monumentos Arquitectónicos de España (1856-1881).

Una vez terminada la construcción del Castelo en 1909, se iniciaron los trabajos de ornamentación y acabado, los más complejos sin duda, no tanto por su dificultad técnica como por requerir mayores esfuerzos de coordinación general. ${ }^{2}$ La arquitectura del islam occidental se caracteriza por reservar al interior la verdadera riqueza del ámbito privado, doméstico y reservado; todo lo cual contrasta con la arquitectura del historicismo decimonónico dominada, precisamente, por la exteriorización de la forma y la apariencia visual. No obstante, el Castelo Mourisco comparte con la Alhambra un primer rasgo como es la monumentalidad y el dominio espacial, pues como ésta, el Instituto se alza sobre un promontorio dominante sobre la bahía de Guanabara; en ambos casos hoy envueltos por frondosos parques.

Pero además, el Castelo aplica de manera deliberada la secuencia material y decorativa de los paramentos de la arquitectura nazarí, es decir, zócalos cerámicos y paños de atauriques, donde el ladrillo visto evoca el arte mudéjar. Al interior, los ámbitos de mayor representatividad como la escalera y la biblioteca, aparecen revestidos por entero de yeserías y zócalos de madera. Todos los techos se recubren también de argamasas y paños de estuco, dando continuidad a la envoltura decorativa, recreando la ambientación alhambrista sin caer en la copia arqueológica. De hecho, los frisos con epigrafía cursiva que recorren muros y techos son en realidad recomposiciones pseudocaligráficas de fragmentos árabes, carentes de sentido gramatical, que incluso en ocasiones se hallan invertidas. 


\section{Los elementos exteriores}

En cualquier caso, la apropiación alhambrista más evidente se corresponde con elementos en origen destinados a patios interiores como son los arcos con albanegas. Las ventanas simples y geminadas de los cuerpos de las torres y fachadas laterales reproducen la forma elemental del arco de herradura con el que Girault de Prangey (1841) ilustra Essai sur l'architecture des arabes et des mores, en Espagne, en Sicile, et en Barbarie. Este frontispicio gráfico parece especialmente apropiado para definir la apariencia general que se pretende del edificio, donde la mirada cercana permite confirmar esa primera impresión morisca. Estampa que se corresponde en realidad con una placa califal de alabastro, conservada en la catedral de Tarragona, adaptada al Castelo mediante la incorporación de columnas nazaríes y un paño decorativo extraído de Plans, sections, elevations and details of the Alhambra, de Owen Jones (1842). En efecto, el capitel con cálatos de cinta continua y palmas envolventes con palmeta gallonada en el ábaco se corresponde con uno de los que soportan el pórtico del Patio de los Leones (Jones, 1842, pl.XLI, n.67); mientras que los arabescos de las enjutas proceden del entonces conocido como Patio de la Mezquita, actual Cuarto Dorado (Jones, 1842, pl.7, n.11). A pesar de su calidad, encontraremos varios casos donde los artesanos que realizaron los moldes para las argamasas procedieron a simplificar los diseños originales suprimiendo las epigrafías.

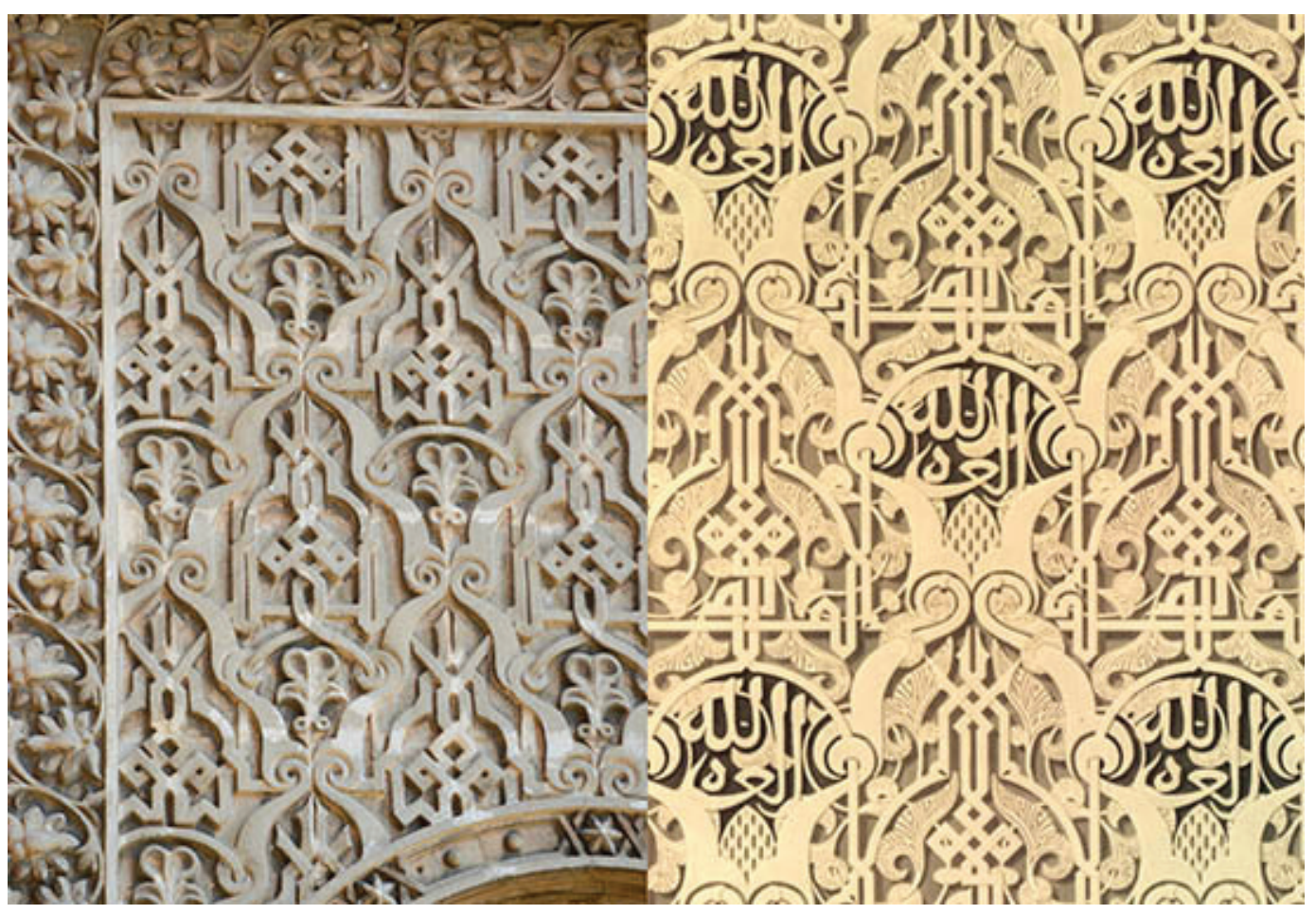

Figura 3: Paño de arabescos del Castelo Mourisco, Río de Janeiro (Acervo personal del autor)
Figura 4: Arabescos del Patio de la Mezquita, Alhambra (Jones, 1842) 
La galería exterior de la planta baja imita la estructura abierta de los pórticos palatinos de los patios nazaríes. La secuencia frontal de cinco arcos, con el central más elevado, sobre columnas dobles, sigue la articulación del pórtico desaparecido del Cuarto Real de Santo Domingo (Granada), aunque con mayor monumentalidad debido a la amplitud de los arcos de medio punto. Su imagen, aunque erróneamente identificada con el Generalife, sería universalmente divulgada por James Cavanah Murphy en The arabian antiquities of Spain (Londres, 1813-1816). ${ }^{3}$ Aunque es la lámina de Owen Jones para Plans..., del pórtico meridional del Patio de los Leones la que aporta detalles complementarios tenidos en cuenta por Moraes como la cenefa recortada de los arcos (Jones, 1842, pl.XXXVIII). Las enjutas repiten el modelo antedicho de las ventanas laterales, sin recurrir a los paños calados originales, si bien orlados con una cenefa de lazo entrecruzado que se inspira en las borduras de los zócalos alicatados. Hacia el interior, el andén se divide en tres tramos mediante arcos de mocárabes, tratando de emular la secuencia espacial de la Sala de los Reyes.

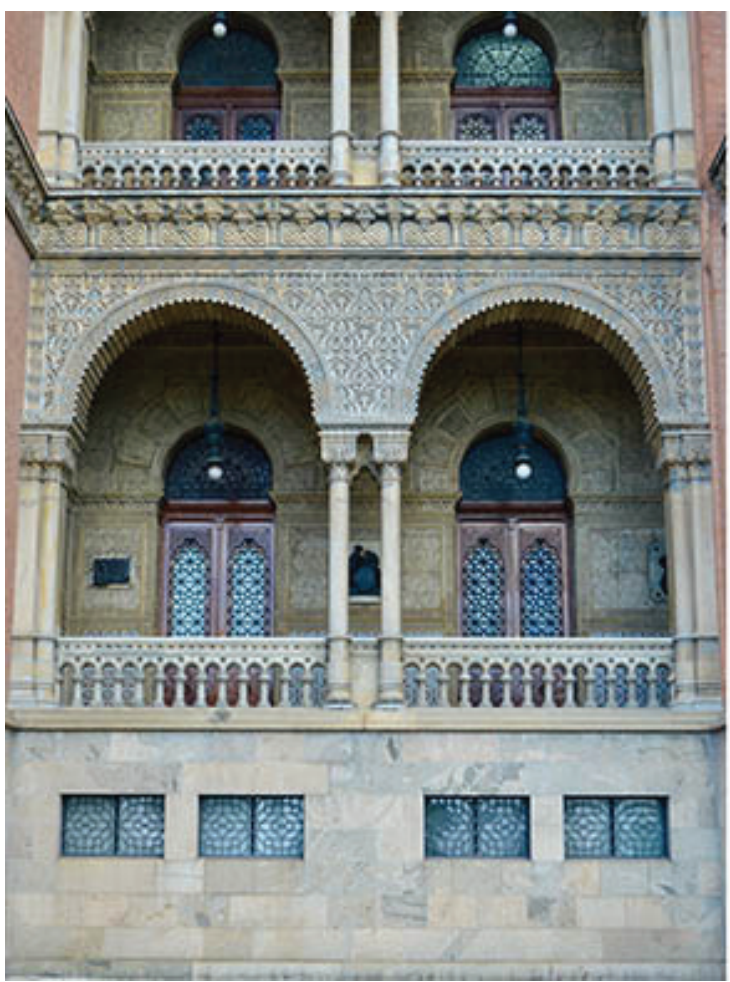

Figura 5: Arcos del Castelo Mourisco, Río de Janeiro (Acervo personal del autor)



Figura 6: Alzado del pórtico del Patio de los Leones, Alhambra (Jones, 1842)

Mayores singularidades ofrecen los arcos de la galería superior, con parejas de arcos sobre dobles columnas cuyo apuntamiento y lóbulos están más próximos a la arquitectura mogol, según se ha visto; aunque también podría relacionarse con los arquillos ciegos de los intradoses de la Sala de Abencerrajes y las cornisas de mocárabes que recorren las cornisas. Al igual que en el resto de andenes, la concordancia se mantiene mediante la compartimentación del espacio en tres tramos. La última balconada queda enmarcada 
por grandes arcos rebajados, a ambos lados del cuerpo central de arco trilobulado. Todos los arcos de estas galerías apoyan sobre columnas neonazaríes, cuyos capiteles responden al tipo dispuesto en los pabellones del Patio de los Leones, según el modelo de cálatos de meandros de doble onda, con flor de lis entre tallos y hojas en el ábaco (Girault de Prangey, 1842). De igual manera, los vanos laterales del belvedere central sustituyen los arcos por el tipo de ménsulas empleadas por la arquitectura nazarí para sostener dinteles, similares a los que reproduce Plans... de la Sala de la Barca (Jones, 1842, pl.XI).



Figura 7: Columna del Castelo Mourisco, Río de Janeiro (Acervo personal del autor)
Figura 8: Elementos decorativos del Palacio de los Leones, Alhambra (Girault de Prangey, 1842)

Por su parte, las fachadas traseras abiertas al patio mantienen una secuencia ordenada de arcos triples de herradura con dovelas alternantes de ladrillo y granito, que recuerdan la bicromía de la sala de oración de la Mezquita de Córdoba. Apoyan sobre pilares con capiteles decorados con greca pseudoepigráfica. No obstante, sin descartar este influjo directo en el pensamiento de Moraes, se trata también de un recurso decorativo habitual en la arquitectura neoárabe francesa por influencia mameluca. En cualquier caso, se repiten los vanos simples con albanegas y columnas adosadas, que en los extremos de las alas laterales se convierten en arcos geminados, muy reducidos, sobre columnas neonazaríes de capiteles de mocárabes estilizados. Por último, las bow windows intermedias lucen idénticas columnas, apoyando arcos triples de herradura, más grande el central que los laterales, tal 
y como se dispone en la entrada al pabellón norte del Generalife. ${ }^{4}$ Las correspondientes al último piso presentan arcos de formas mixtilíneas, similares a los de la balconada principal, de influencia mogol como se ha referido.

Asociado a este repertorio ornamental desplegado al exterior, cabe señalar los elementos de evidente influjo alhambrista que se desarrollan en el interior de las balconadas de la fachada principal. Los motivos ornamentales del arte nazarí fueron entonces utilizados como fuentes de inspiración, cuando no directamente para su recreación, por su superioridad frente al ornamento árabe, más imperfecto y monótono. Además de su aniconismo, se ponderaba la simplicidad formal basada en formas rigurosas y el cromatismo, que en su entrelazo y multiplicación infinita podían generar imágenes exuberantes y suntuosas. Decoraciones geométricas de lazo se aplicaron así a los pavimentos, desde los interiores a los empedrados que circundan el área externa del edificio, cuyas piedras fueron importadas directamente desde Portugal. La importancia de estas calçadas portuguesas - conocidas en Brasil como pedras portuguesas - radica en los diseños de lacerías, infrecuentes en los empedrados granadinos y andaluces.

Por su parte, los mosaicos de las galerías recurren a patrones alhambristas, como si se tratase de almatrayas que continuaban el efecto textil de las jambas en las estancias de verano de la Alhambra. Recorre todo el andén del piso una composición de grandes estrellas de doce, formadas por un lazo anaranjado, antes vinculado a la carpintería ataujerada que a los zócalos cerámicos; si bien muestra importantes similitudes con el friso de yeso de grandes ruedas que rodea el Salón de Comares bajo las celosías. Por su parte, la galería superior presenta una lacería semejante a los alicatados nazaríes, con parejas de estrellas de ocho en tonalidades contrastadas de ocre, azul, rojo oscuro y negro. Por último, el mosaico que cubre la última galería supone una simplificación del intrincado lazo del alicatado que rodea la Sala de Dos Hermanas, manteniendo en cierta manera idéntica combinación de tonos. Para el resto de pavimentos, alféizares y soleras de puertas y ventanas se empleó mármol de Carrara, con el que también se construyó la escalera principal.

Independientes en técnica y diseño, los azulejos que conforman el zócalo de la galería de la planta baja responden a uno de los modelos de inspiración alhambrista más difundidos por la Fábrica de Faianças das Caldas da Rainha desde finales del siglo XIX. Su diseño formaba parte de la recopilación de patrones nazaríes y mudéjares llevada a cabo por Rafael Bordalo Pinheiro y que comercializó dentro de la línea de azulejería y materiales de construcción, junto con la más creativa de cerámica utilitaria y piezas decorativas (Melo, 2014). Se trata de un complejo trazado de lacería donde cuatro azulejos componen un rueda de doce, partiendo de un sino anaranjado y candilejos azules, para formar ruedas intermedias de ocho. El prototipo sobre el que se elaboró este diseño simplificado procede del alicatado de la alcoba del sultán en el Salón de Comares. En su versión menos refinada "de cuerda seca" y vidriada, estos azulejos resultaban aptos para la decoración exterior, creando abundantes brillos y variados efectos cromáticos.

Por su parte, los alizares que recorren la galería exterior de la segunda planta, si bien inspirados en patrones alhambristas, responden a una tipología diferente. Se trata de azulejos relevados en los que domina una viva policromía tomando como modelo los alicatados de la Sala del Mexuar, procedentes de la desaparecida Sala de las Helias. Se articulan en 
torno a ruedas completas de dieciséis, con sinos azules, almendrillas blancas, alfardones negros y candilejos blancos; en torno a las cuales se ordenan otras ruedas más pequeñas de zafates anaranjados y verdes, alrededor de estrellas de ocho también azules con almendrillas blancas. Se trata de una versión colorista sobre la rueda de zafates verdes y el octógono de costadillos negros del paño original, reproducida mediante azulejos mudéjares en el Palacio da Vila de Sintra (Jones, 1842, pl.XLIII).

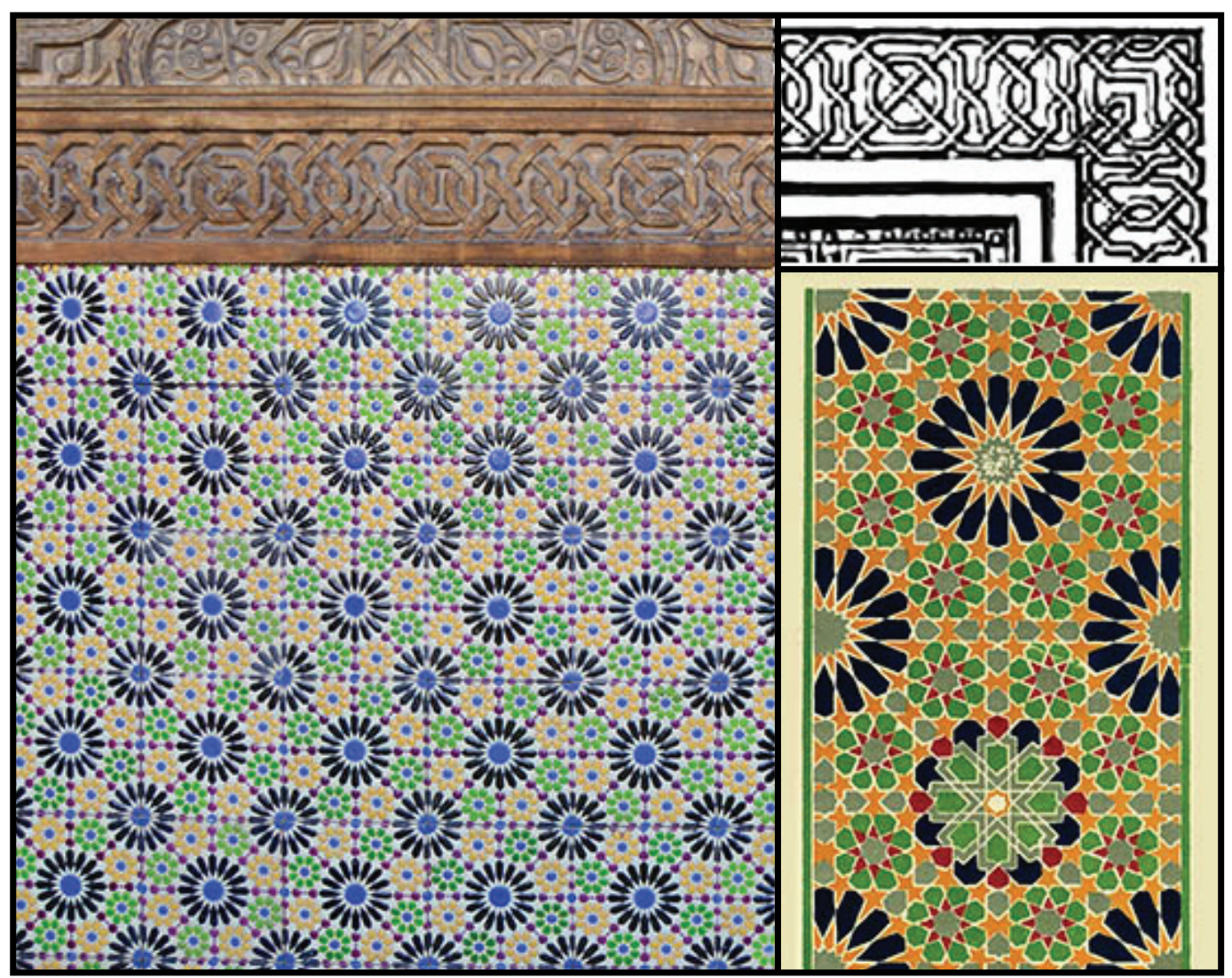

Figura 9 (izquierda): Zócalo de azulejos del Castelo Mourisco, Río de Janeiro (Acervo personal del autor) Figura 10 (derecha arriba): Cenefa geométrica de la Sala de las Dos Hermanas, Alhambra (Jones, 1842) Figura 11 (derecha abajo): Zócalo de alicatado de la Sala del Mexuar, Alhambra (Jones, 1842)

Con todo, la actividad más creativa desarrollada por Moraes sería el diseño de los patrones decorativos para aquellos elementos no susceptibles de fabricación industrial y que, por tanto, debían ser realizados ex profeso. Las argamasas de cemento que conforman las enjutas de los arcos de las fachadas siguen un único patrón decorativo integrado por varios niveles superpuestos, constituidos por formas mixtilíneas de sebka enmarcando un lazo decorativo entrecruzado y motivos vegetales esquemáticos. Procede el modelo original de la decoración del arco central de acceso al Cuarto Dorado, habiéndose simplificado el lazo epigráfico de alabanza a Dios. Por el contrario, el alfiz contiene una guirnalda de palmetas de filiación clásica. No obstante, el intradós de los arcos de los pórticos repite la trama vegetal superpuesta que lucen las arquerías del Patio de los Arrayanes. Por su 
parte, los muros interiores de las galerías de la fachada principal aparecen completamente recubiertos de estas decoraciones imitando yeserías, para cuyas partes centrales se optó por ricos trazados regulares de rosetones lobulados que parten de estrellas y motivos vegetales en varios niveles. Identificables serían los de la galería baja, inspirados en las yeserías del patio del Cuarto Dorado (Jones, 1842, pl.XX, n.32); de igual modo que los paneles murales siguen el patrón geométrico dominante en el Salón de Comares (pl.VI, n.10), o las cenefas con cadenetas que enmarcan los paños de azulejos procedentes de la Sala de Dos Hermanas (pl.XIX). Otras composiciones no ofrecen tanta sumisión a los patrones originales, como ocurre con la cenefa vegetal que recuerda uno de los atauriques del pórtico del Patio de los Arrayanes (pl.XXXIII).

\section{Las decoraciones interiores}

Junto con los detallados diseños para las rejerías, conserva el acervo de la propia Fundación algunos proyectos originales para los zócalos de madera y los estucos de la escalera. Tratándose de un espacio interior, y por tanto protegido de la intemperie, se optó por materiales cálidos, aunque ello supusiera incumplir la ortodoxia estilística. En este sentido, las vivas policromías de los alicatados y yeserías nazaríes fueron reducidas a planos monocromos, traspasándose la riqueza multicolor al mosaico del pavimento. El pino, la canela y la peroba, tanto amarilla como blanca, fueron las maderas utilizadas en la carpintería procedente de las serrerías locales de Francisco Pereira Passos e Hijos, A. J. de Araujo \& Cia. y Domingos Joaquim da Silva \& Cia. Las puertas en peroba fueron talladas por Raphael Torelli y todos los elementos de cerrajería fabricados por la empresa norteamericana Yale. Una sucesión de arcos trilobulados con tres arquillos superiores cada uno recorren la base de los muros de la escalera, que parece inspirado en motivos presentes en la Sala del Mexuar, Cuarto Dorado y Oratorio del Partal. Ello contrasta con la viveza de los mosaicos que adornan la escalera principal, cuyos diseños claramente orientales se vinculan con el turkish style, a cuyos patrones textiles se acude. En efecto, la apariencia geométrica de las teselas cuadradas imita el nudo ghiordes, buscando reproducir la calidez del pavimento alfombrado en esta área de recepción.

Por su parte, los estucos aplicados al resto de los paramentos y techos constituyen un entramado continuo y difuso donde las referencias alhambristas son evidentes, pero sin llegar a repetir modelos concretos. La monocromía general - igual que en las argamasas exteriores y las yeserías de la biblioteca - buscaba imitar el aspecto actual de los arabescos alhambreños, desprovistos de su policromía original por el paso del tiempo. El recurso al dorado aplicado en esta zona interior - hoy poco perceptible - podría estar justificado por la voluntad de manifestar un espacio suntuoso y atractivo, así como por su mayor capacidad para reflejar la luz tanto natural como artificial.

La necesidad de recubrir una gran superficie irregular debió determinar la elaboración específica, antes que la importación de vaciados de arabescos; lo que determinó una mayor libertad formal a la hora de dibujar los motivos que debían ejecutar los artesanos y luego dorar. Los paños de motivos romboidales constituyen una composición habitual en las decoraciones parietales de la Alhambra, hallando algunas similitudes con el sistema 
de losanges presentes en el espacio central del Oratorio del Partal. No obstante, ciertas semejanzas, a pesar de su simplificación, puede advertirse también con las yeserías del Salón de Comares (Jones, 1842, pl.XXXVI; Bisson, 1853, pl.6). Por su parte, los finos listeles triples de motivos entrelazados y ondulantes que enmarcan estos paños resultan igualmente de la reelaboración de modelos presentes en otras áreas de los palacios nazaríes. Respecto al trazado de los estucos que recubren los techos de la escalera, componen un intrincado diseño de varias tramas compositivas con doble lazo de ocho de estrellas y crucetas. Así, la primera trama con cinta de cadenetas forma crucetas y círculos lobulados, mientras que la segunda compone círculos y ruedas de ocho con cinta, quedando el fondo cubierto con decoración vegetal lisa y digitada.

El cuidado en la ornamentación del Instituto llegaba hasta el trazado de las balaustradas y rejerías, en rigoureux style mauresque, para las que Moraes elaboró hasta dieciocho diseños diferentes, que fueron realizados en hierro forjado en Alemania e importadas por Carlos Schlosser \& Cia. en 1909. Debe destacarse el elaborado trazo de la jaula que protege el hueco del ascensor, imitando lacería. Las rejas constaban de un armazón de hierro de composición reticular hacia las jambas y más tupida en el círculo del arco, centrada por estrellas de tamaño variable, desde la figura de cinco puntas a la rosa náutica, pasando por el Sello de Salomón. Aunque estas formas resultan variaciones sobre modelos habituales en la decoración musulmana, el arquitecto dio rienda suelta a su imaginación a la hora de concebir piezas que sirvieran para tamizar la intensa luz tropical a modo de celosía. No obstante, la actividad laboral cotidiana justificaba la presencia de luz blanca mediante vidrios traslúcidos en los vanos de puertas y ventanas, quedando reducidos los vivos juegos de colores a los lucernarios de la escalera y acceso principal, elaborados por Forment \& Co., y donde el arquitecto diseñó originales composiciones bajo el influjo de los alicatados nazaríes. De esta forma, el vestíbulo de entrada reinterpreta la estructura de $q u b b a$, conformada como un espacio rectangular abierto en toda la altura del edificio y cerrado con una claraboya coloreada, y dentro del cual se despliega la escalera imperial de hierro que permite acceder a los pisos superiores. El ambiente de intimidad y los claroscuros generados mediante esa integración ante las cristaleras recuerda el recreado por William Klein y Albert Duclos en "Le Hammam" (1876) de París, cuya imagen publicitaria con fotografías de Nadar alcanzó una insólita difusión.

\section{La sala de lectura de la biblioteca}

De todo el conjunto, el área que muestra un mayor desarrollo ornamental es, sin duda, la sala de lectura de la biblioteca, situada en la tercera planta del ala norte. Su función como salón para albergar las reuniones semanales donde se discutían las conclusiones de las investigaciones, justifica la calidez ambiental propia del interiorismo neomusulmán. Semanalmente se montaba sobre la mesa central una muestra con los ejemplares de revistas científicas recién llegados a una biblioteca que aspiraba a ser el principal depósito de información en Ciencias Biomédicas de Latinoamérica, de modo que la comunidad científica que integraba el Instituto pudiese estar al corriente de las últimas investigaciones. En torno a este espacio, Oswaldo Cruz presidía cada miércoles una sesión de lectura y discusión llamada mesa das quartas-feiras - en torno a las últimas investigaciones publicadas (Sousa, 
2006, p.12). La preocupación de Oswaldo Cruz por la actualización constante debió marcar el diseño de la sala, luminosa, accesible y agradable, suficiente para incentivar su uso y disfrute. ${ }^{5}$

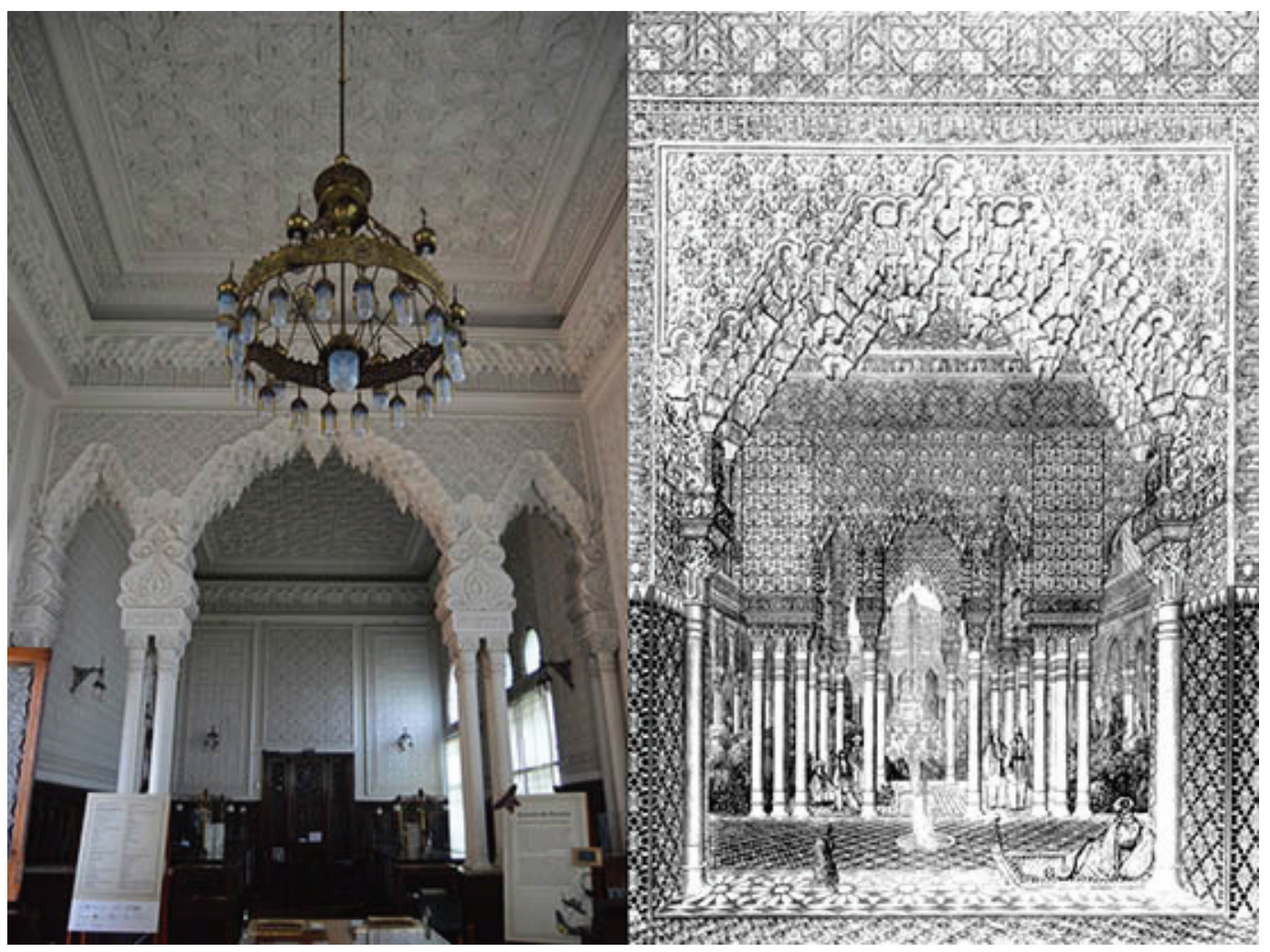

Figura 12: Cancel de la Sala de Lectura del Castelo Mourisco, Río de Janeiro (Acervo personal del autor)

El elemento que captura la atención desde la entrada es el cancel de separación entre la zona de catálogos y la dedicada al estudio. Se trata de una estructura que imita la arcada lateral de los pabellones del Patio de los Leones de la Alhambra, integrada por un triple arco de mocárabes, más estrechos y apuntados los laterales respecto del central. Precisamente, y adaptado a la anchura del salón, este arco central adquiere una mayor luz y altura respecto de su modelo. Los paños calados nazaríes son aquí sustituidos por albanegas con estucos que imitan uno de los diseños en yeso que recubre la Sala de Dos Hermanas, centrado por una estrella de ocho puntas, y repetido en los paneles verticales de las paredes. La base de los arcos incorpora cuatro flores de lis de gran tamaño, sobre cimacios decorados con arabescos que apoyan en columnas neonazaríes, emparejadas en grupos de cuatro, y cuyos capiteles son similares a los dispuestos en las fachadas. Los paños murales repiten el diseño de las albanegas del cancel cuyo origen se halla en un zócalo cerámico de la Alhambra, presente también en el mudéjar portugués en los azulejos del tipo "pé de galo" que decoran el patio central del Palacio Nacional de Sintra. Este diseño, en argamasa, también se aplica en los arcos exteriores del Castelo. 




Figura 14: Paño de estuco de la Sala de Lectura del Castelo Mourisco, Río de Janeiro (Acervo personal del autor)

Figura15: Paño geométrico del Patio de los Leones, Alhambra (Jones, 1842)

Por su parte, el friso de mocárabes que discurre bajo la techumbre podría hallar su paralelismo formal en las cenefas de los vanos del Salón del Trono, de arquillos dobles sobre columnillas y fondo de ataurique y epigrafía (Jones, 1842, pl.XXVIII, n.41). Por último, el techo se recubre por entero de decoración en yeso, siguiendo el horror vacui ornamental del arte nazarí, aun no tratándose de una estructura de madera tallada, como es habitual en la Alhambra. En este caso, se recurre nuevamente a un trazado de lacería con estrella de ocho, muy próximo al desarrollado en los muros.

A pesar del carácter detallista de esta recreación ambiental, la parte inferior de las paredes está recorrida por un elevado zócalo de madera tallada, ejecutado por Raphael Torelli, con el cual se integra el pavimento de marquetería. Presenta una sucesión de arcos de herradura sobre columnillas neonazaríes, en una combinación cromática y material que recuerda los diseños del italiano Carlo Bugatti. El resto del mobiliario - mesas, sillas, ficheros - mantiene la filiación oriental del conjunto, incluyendo los apliques y lámparas realizados en Alemania en bronce dorado y decorados con opalinas azul, lila, roja y verde. El carácter general de la biblioteca del Instituto de Manguinhos reitera la voluntad de Oswaldo Cruz de suscitar un clima general de trabajo donde la funcionalidad no estuviese reñida con la sofisticación, reforzando esa percepción de su extraordinaria sensibilidad hacia la información como un patrimonio valioso e indispensable en la búsqueda del conocimiento (Sousa, 2006, p.62).

\section{Consideraciones finales}

Como faro que ilumine un nuevo tiempo, sin epidemias ni enfermedades contagiosas, queda justificada la apariencia singular y elocuente del Castelo Mourisco, "magnifica mesquita da sciencia brasileira" (Penna, 1922, p.113). Monumento conmemorativo del triunfo de la ciencia sobre la enfermedad, la ignorancia, los prejuicios y los intereses 
privados. La Facultad de Medicina de Montevideo calificaba en 1929 este centro como "augusto templo de la ciencia" (Homenagem..., 1929, p.200). Todo lo cual justifica las diferentes opciones estilísticas que, aglutinadas y convenientemente combinadas, dieron lugar a una obra del todo original, tan sorprendente, atractiva y sugerente como pudiera ser la propia Alhambra de Granada. Esta "fábrica científica" (Los congresos..., 1929, p.148) aspiraba a ser el nuevo Instituto Pasteur al otro lado del océano, convertida en el más digno y grande monumento a la memoria de Oswaldo Cruz. Como proclamaba orgulloso Ruy Barbosa (1999, p.55), emergía en Manguinhos "o palacio da sciencia brasileira, da nossa sciencia viva e productiva".

\section{NOTAS}

\footnotetext{
${ }^{1}$ Los primeros proyectos de Moraes incorporaban en los extremos superiores de la fachada principal sendos medallones con cabezas de científicos contemporáneos, uno de los cuales podría representar a Louis Pasteur.

${ }^{2}$ El cese de Cruz como director general de Salud Pública provocó un descenso drástico de los fondos públicos destinados a la construcción, que se prolongó hasta 1918, un año después de la muerte del promotor.

${ }^{3}$ Esta estampa (Jones, 1842, pl.345) sería incluida en el libro de Calvert.

${ }^{4}$ Una fotografía de Rafael Garzón (pl.343) incluye Calvert (1906) en su obra sobre la Alhambra.

${ }^{5}$ Incluso los libros eran encuadernados según una cuidada decoración alhambrista, en una sala contigua (Dias, 1940, p.107).
}

\section{REFERENCIAS}

BARBOSA, Ruy.

Oswaldo Cruz: discurso pronunciado na sessão cívica de 28 de maio de 1917, no Theatro Municipal. Rio de Janeiro: Casa de Rui Barbosa. 1999.

BENCHIMOL, Jaime.

Manguinhos, do sonho à vida: a ciência na Belle Époque. Rio de Janeiro: Casa de Oswaldo Cruz/ Fiocruz. 1990

BISSON, Louis y Auguste.

Choix d'ornements arabes de l'Alhambra offrant dans leur ensemble une synthèse de l'ornementation mauresque en Espagne au XIIIe siècle. Paris: G. \& J. Baudry. 1853.

BRENNA, Giovanna Rosso del.

Ecletismo no Rio de Janeiro (séc. XIX-XX). In: Fabris, Annateresa (Org.). Ecletismo na arquitetura brasileira. São Paulo: Nobel; Edusp. p.28-67. 1987.

BUSH, Olga.

The architecture of jewish identity: the neoislamic central synagogue of New York. Journal of the Society of Architectural Historians, n.63, p.180-201. 2004.

CALVERT, Albert.

The Alhambra: being a brief record of the Arabian conquest of the Peninsula with a particular account of the Mahommedan architecture and decoration. London: John Lane. 1906.

CAVEDA, José.

Memorias para la historia de la Real Academia de Bellas Artes de San Fernando y de las Bellas Artes en España. t.11. Madrid: Imp. Manuel Tello. 1867.

COSTA, Renato da Gama-Rosa.

Arquitetura neo-mourisca no Rio de Janeiro. In: Costa, Renato da Gama-Rosa (Org.). Caminhos da arquitetura em Manguinhos. Rio de Janeiro: Casa de Oswaldo Cruz/Fiocruz. p.77-87. 2003.

COSTA, Renato da Gama-Rosa.

Luiz de Moraes Júnior e a contribuição ao ecletismo na arquitetura brasileira. In: AA. VV. Anais do Colóquio Brasileiro: redescobertas. Belo Horizonte; Cuiabá: Instituto dos Arquitetos do Brasil. p.38. 1999.

DIAS, Mario Vianna.

O Instituto Oswaldo Cruz. Arquivos de Medicina Legal e Identificação, v.10, n.18, p.98-107. 1940.

EFRON, John M.

German jewry and the allure of the sephardic. Princeton: University Press. 2016.

FERNANDES, Carlos B.

Manguinhos. Jornal do Brasil, p.5. 24 jan. 1920. 
GIRAULT DE PRANGEY, Joseph-Philibert. Choix d'ornements moresques de L'Alhambra. Paris: A. Hauser. 1842.

GIRAULT DE PRANGEY, Joseph-Philibert. Essai sur l'architecture des Arabes et des Mores, en Espagne, en Sicile, et en Barbarie. Paris: A. Hauser. 1841.

\section{HOMENAGEM...}

Homenagem à memória de Oswaldo Cruz. Memórias do Instituto Oswaldo Cruz, v.9, n.22, p.200-203. 1929.

JONES, Owen.

Plans, elevations, sections, and details of the Alhambra: from drawings taken on the spot in 1834. London: Owen Jones. 1842.

KNOBLAUCH, Gustav.

Die neue Synagoge in Berlin. Zeitschrift für Bauwesen, n.17, p.3. 1868.

KNOBLAUCH, Gustav.

Die neue Synagoge in Berlin. Zeitschrift für Bauwesen, n.16, p.481-486. 1866.

KNOBLAUCH, Gustav.

Die neue Synagoge in Berlin. Zeitschrift für Bauwesen, n.15, p.273. 1865.

KOOLHAAS, Rem. Conversations with students. Houston; New York: Princeton Architectural Press. 1996.

LABRUSSE, Rémi (Ed.).

Purs décors? Arts de l'islam, regards du XIXe siècle.

Paris: Les Arts Décoratifs et Musée du Louvre. 2007.

LA ENSEÑANZA...

La enseñanza de la medicina en el Brasil. Nuestro

Tiempo, Ciencias y Artes - Política y Hacienda, n.296, p.225. 1923.

\section{LOS CONGRESOS...}

Los congresos médicos reunidos en Río de Janeiro, de 30 de junio a 7 de julio de 1929. Boletín de la Revista Ibero-Americana de Ciencias Médicas, n.41, p.144-148. 1929.

MAURY, Gilles.

Le château Vaissier: palais orientaliste d'un savonnier de Roubaix (1892-1929). Paris: Picard. 2013.

MELO, Renata Barros de.

El neomedievalismo islámico en el Castelo Mourisco de Río de Janeiro (Brasil): la adaptación del modelo alhambrista. Dissertação (Mestrado) Facultad de Filosofía y Letras, Universidad de Granada, Granada. 2014.

NEEDELL, Jeffrey D.

A tropical belle epoque: elite culture and society in turn-of-the-century Rio de Janeiro. New York: Cambridge University Press. 1987.
OLIVEIRA, Benedito Tadeu.

Da antiga sede da Diretoria Geral de Saúde Pública (DGSP) ao atual Instituto Nacional do Câncer (Inca). História, Ciências, Saúde Manguinhos, v.14, n.1, p.325-346. 2007.

PENNA, Bélisario.

Oswaldo Cruz, impressões de um discípulo. Rio de Janeiro: Imprensa Official do Estado. 1922.

REIS, José Oliveira.

O Rio de Janeiro e seus prefeitos: evolução urbanística da cidade. Rio de Janeiro: Prefeitura da Cidade. 1977.

ROCHA-PEIXOTO, Gustavo.

O ecletismo e seus contemporâneos na arquitetura do Rio de Janeiro. In: Czajkowski, Jorge (Org.). Guia da arquitetura eclética no Rio de Janeiro. Rio de Janeiro: Centro de Arquitetura e Urbanismo. p.5-24. 2000.

RODRÍGUEZ DOMINGO, José Manuel.

Adolfo Morales de los Ríos y García de Pimentel. In: López Guzmán, Rafael; Gutiérrez Viñuales, Rodrigo (Org.). Alhambras: arquitectura neoárabe en Latinoamérica. Granada: Almed. p.205-210. 2016

RODRÍGUEZ DOMINGO, José Manuel.

La asimilación neomusulmana en la arquitectura de Río de Janeiro. Quiroga, n.1, p.30-41. 2012.

RODRÍGUEZ DOMINGO, José Manuel; BARROS, Renata de Melo.

Influencia y apropiaciones estilísticas en el

"Castelo Mourisco" de Río de Janeiro. In:

López Guzmán, Rafael et al. (Org.). América: cultura visual y relaciones artísticas. Granada: Universidad. p.229-238. 2015.

SENCE, Michel.

Le château mauresque ou les rêves d'Orient d'un industriel cominois à la fin du XIXe siècle. Mémoires de la Société d'Histoire de CominesWarneton et de la région, n.47, p.145-154. 2017.

SOUSA, Alexandre Medeiros Correia de. Estudo de uma experiência de fluxo informacional científico no Instituto Oswaldo Cruz: a "Mesa das Quartas-Feiras". Niterói: UFF; Rio de Janeiro: Ibict. 2006.

VAN BAARLE, Caspar.

Rerum octennium in Brasilia et alibi gestarum. [S.1.: s.n.]. 1648.

ZEITUNGSNACHRICHTEN...

Zeitungsnachrichten Deutschland. Allgemeine Zeitung des Judenthums, n.38, p.604. 18 sept. 1866. 